UNITED STATES DEPARTMENT OF THE INTERIOR GEOLOGICAL SURVEY

INVESTIGATION OF AN AEROMAGNETIC ANOMALY

ON WEST SIDE OF YUCCA MOUNTAIN, NYE COUNTY, NEVADA

by

G. D. Bath and C. E. Jahren

Open-File Report 85-459

Prepared in cooperation with the

Nevada Operations Office

U.S. Department of Energy

(Interagency Agreement DE-AI08-78ET44802)

This report is preliminary and has not been reviewed for conformity with U.S. Geological Survey editorial standards and stratigraphic nomenclature. Company names are for descriptive purposes only and do not constitute endorsement by the U.S. Geological Survey.

Denver, Colorado

1985 
Abstract......................................... 1

Introduction.$\ldots \ldots \ldots \ldots \ldots \ldots \ldots \ldots \ldots \ldots \ldots \ldots \ldots \ldots \ldots \ldots \ldots \ldots \ldots \ldots \ldots$

System of magnetic units............................. 3

Acknowledgments................................... 3

Observed, residual and smoothed anomalies...................... 4

Magnetic properties...................................... 4

Estimate of magnetization........................... 11

Anomaly interpretations................................... 13

Aeromagnetic anomalies............................. 15

Ground magnetic anomalies............................ 15

Discussion............................................ 21

References Cited....................................... 22 


\section{ILLUSTRATIONS}

Figure 1.--Residual aeromagnetic map of southern

Page part of potential repository site...................

2.--Topograhic map of area west of Yucca

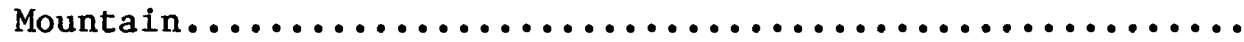

3.--Aeromagnetic anomalies and altimeter records

for traverses A, B, C, and D...................... 6

4.--Residual and smoothed anomalies on traverse A82.......... 7

5.--Residual and smoothed anomalies on traverse A83.......... 8

6.--Residual and smoothed anomalies on traverse B83........... 9

7.--Residual and smoothed anomalies on traverse C83.......... 10

8.--Geologic map of western part of Yucca Mountain............ 14

9.--Section along air traverse $B-B^{\prime}$ over models of dipole, source $A$, and source B.................... 16

10.--Section along ground traverse $C-C^{\prime}$ over models of Solitario Canyon fault, source $C$ and source D......................................

TABLES

Table 1.--Magnetic properties and thicknesses of units penetrated in three drill holes.....................

2.--Total magnetizations for models of figure $9 . \ldots \ldots \ldots \ldots \ldots \ldots$

3.--Aeromagnetic anomalies computed for models of

figure $9 . \ldots \ldots \ldots \ldots \ldots \ldots \ldots \ldots \ldots \ldots \ldots \ldots \ldots \ldots \ldots \ldots . \ldots \ldots$

4.--Total magnetizations of component parts of

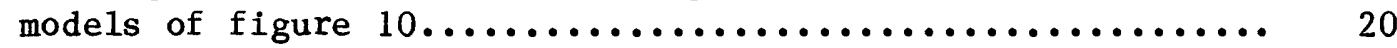

5.--Ground magnetic and aeromagnetic anomalies computed for models of figure $10 \ldots \ldots \ldots \ldots \ldots \ldots \ldots \ldots \ldots$ 


\author{
UNITED STATES \\ DEPARTMENT OF THE INTERIOR \\ GEOLOGICAL SURVEY
}

\title{
INVESTIGATION OF AN AEROMAGNETIC ANOMALY ON WEST SIDE OF YUCCA MOUNTAIN, NYE COUNTY, NEVADA
}

\section{By}

\section{G. D. Bath and C. E. Jahren}

\begin{abstract}
Investigations of the source of a prominent aeromagnetic anomaly of 290 $\mathrm{nT}$ were undertaken at a potential repository site located in the Yucca Mountain area, Nevada Test Site. The anomaly was detected on a recent flight line of a survey flown north-south at $400 \mathrm{~m}(1,300 \mathrm{ft}$ ) spacing and $122 \mathrm{~m}$ ( 400 $\mathrm{ft}$ ) above the surface. The anomaly was not detected on older lines flown east-west at the same spacing and altitude above the surface. The anomaly, which is on the high-standing side of a major fault, was interpreted previously as arising from either an increase of magnetization within a volcanic tuff or a small intrusive feature. Ground magnetic traverses were run to locate the ground maximum, and to delinate anomalies in a traverse that crosses the ground maximum and the nearby fault. Both air and ground anomalies were analyzed using geologic data from surface mapping and drill holes, and magnetic property data from drill holes. The anomaly is caused by contributions from at least three sources. The elevated topography gives a terrain effect since the altitude is decreased between the airplane and exposed Topopah Spring Member of the Paintbrush Tuff. Ground anomalies $300 \mathrm{~m}$ $(1,000 \mathrm{ft})$ south of the air maximum indicate either an increase in magnetization or the presence of a small intrusive body. Finally, there is an increase in magnetic influence from the nearby Solitario Canyon fault.
\end{abstract}

\section{INTRODUCTION}

Studies of air and ground magnetic surveys by Bath and Jahren (1984) have provided structural information at and near the potential site for storage of radioactive waste at Yucca Mountain near the southwestern border of the Nevada Test Site for the Nevada Nuclear Waste Storage Investigations project of the U.S. Department of Energy. The air data consist of a high-altitude survey at a barometric elevation of $2,450 \mathrm{~m}(8,000 \mathrm{ft})$, and two low-altitude surveys about $120 \mathrm{~m}$ ( $400 \mathrm{ft}$ ) above the surface. One was flown east-west to investigate anomalies along major faults striking about north-south, and one was flown north-south to investigate anomalies trending across the site striking about east-west. The general distribution of contours in the two low-altitude surveys is similar, and differences in detail become plausible after considering difference in position and direction of flight paths. However, a prominent anomaly of $290 \mathrm{nT}$ was detected on one north-south line that was not revealed on nearby east-west lines. It is located on figure 18 of Bath and Jahren (1984), and on figure 1 of this report. 


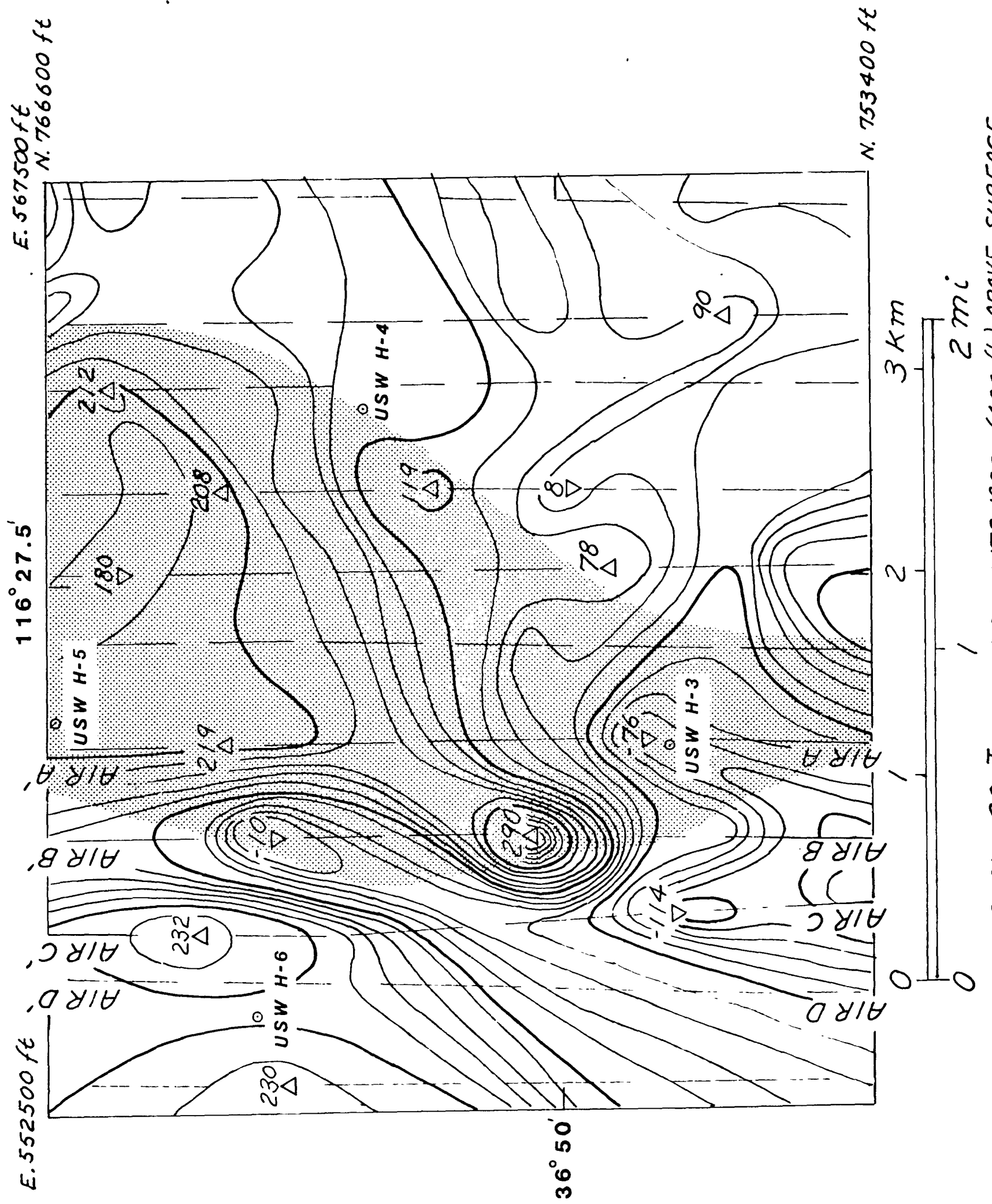

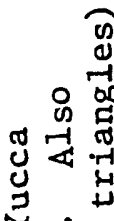

$\frac{4}{5}$

- $\dot{\theta}$

(1)

(4)

o 5

苋近记

के

क

$\rightarrow H$

र

藏它

엄둉

की

0 ० व

○ क व

V

ह ते क्षे

( ) म

ㄴ.

S

$\stackrel{0}{2}$

ए

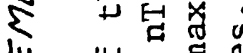

《

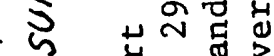

ए तु

w

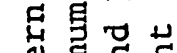

- 至矛实

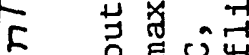

O क

N

110 少

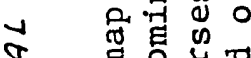

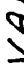

$\frac{1}{\alpha}$

엄

0 员劣

पु 00 \&

Q ⿷匚 क क

की

के है

ถั

$\frac{\alpha}{6}$

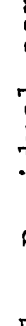

ते त्व

-1

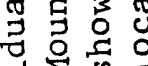

- ${ }^{\circ}$ 的

os

米

$\dot{-1}$

岁 
Yucca Mountain is underlain by a thick sequence of ash-flow tuffs and tuffaceous sediments, and subordinate amounts of lava flow and flow breccia. The volcanic rocks are of Tertiary age and attain a combined thickness of more than $1,829 \mathrm{~m}(6,000 \mathrm{ft})$. Pre-Tertiary rocks consist of sedimentary rocks with the possibility of igneous intrusions. A positive anomaly in the highaltitude aeromagnetic survey over exposures of strongly magnetized argillite of the Eleana Formation (Mississipian-Devonian Age) at Calico Hills extends westward $20 \mathrm{~km}$ into the site area where interpretations give an argillite thickness of $800 \mathrm{~m}(2,625 \mathrm{ft})$ at a depth of $2,250 \mathrm{~m}(7,400 \mathrm{ft})$. The high magnetite content of the argillite is not typical of the region, and was probably introduced by the heating effects of an underlying pluton. Pairs of positive and negative anomalies in the low-altitude aeromagnetic data are interpreted as major nearby faults that do not cross the site area.

This report was prepared to present 1982 and 1983 measurements of ground magnetic anomalies that were made to locate the position of the $290 \mathrm{nT}$ anomaly on the ground, and to investigate the effects of magnetized geologic structures that could produce the anomaly. Bath and Jahren (1984) suggested the anomaly could be explained by either an increase of magnetization within normally magnetized ash flows or the presence of a small intrusive body. The suspected ash flows are the Topopah Spring Member of the Paintbrush Tuff, which is exposed at the surface, and the Bullfrog Member of the Crater Flat Tuff, which is at a depth of about $600 \mathrm{~m}(1,950 \mathrm{ft})$ below the surface. An investigation of flight records reveals another possibility. Radio altimeter measurements show an abrupt decrease in the flight altitude across the anomaly source, and this decrease in effective depth to the Topopah Spring Member will produce an increase in anomaly amplitude.

\section{System of Magnetic Units}

All magnetic units are given in the International System of units (SI). Conversions to the older electromagnetic units (emu) are given in the following table:

\begin{tabular}{lll}
\hline \multicolumn{1}{c}{ Quantity } & SI units & $\begin{array}{c}\text { Equivalent unit } \\
\text { (in emu) }\end{array}$ \\
\hline Magnetic field & Nanotesla (nT) & $1 \mathrm{nT}=1$ gamma $=10^{-5}$ oersted \\
Magnetization & Ampere/meter $(\mathrm{A} / \mathrm{m})$ & $1 \mathrm{~A} / \mathrm{m}=10^{-3}$ gauss \\
\hline
\end{tabular}

\section{Acknowledgments}

Several geologists and geophysicists have contributed to this report and their assistance is gratefully acknowledged. In particular, thanks go to $R$. B. Scott and R. W. Spengler for discussing relations of magnetic anomalies to the geologic features of Yucca Mountain, and Erick Esham for assistance in surveying locations of ground magnetic traverses. J. G. Rosenbaum provided the magnetic property data and wrote the three-dimensional forward program used in the model studies. 


\title{
OBSERVED, RESIDUAL, AND SMOOTHED ANOMALIES
}

The observed data recorded by a magnetometer during an aeromagnetic or ground magnetic survey consist of the anomalies from the geologic features being studied plus the combined effects of the undisturbed geomagnetic field, magnetized sources deep within the Earth's crust, and man-made objects near the surface. Residual anomalies are those that remain after the Earth's field and effects of deep sources and man-made objects are removed from the observed data. The change in the Earth's field was eliminated from aeromagnetic data by removing the International Geomagnetic Reference Field (Barraclough and Fabiano, 1978), and from ground magnetic data by removing increases of 5.64 $\mathrm{nT} / \mathrm{km}$ northward and $1.72 \mathrm{nT} / \mathrm{km}$ eastward. Effects of deep crustal sources were mostly eliminated by adjustment of observed data to an assumed zero field near Mercury in the southeastern corner of the Nevada Test Site (Bath and others, 1983). The zero field is the average value measured over a large area of nonmagnetic sedimentary rocks that are assumed to extend to great depths. Observed ground anomalies in areas near drill casing and other iron and steel objects are considered unreliable and therefore omitted from the data.

Residual anomalies were compiled for four air traverses and five ground traverses in the vicinity of the prominent aeromagnetic anomaly, and locations of traverses are given on the topographic map of figure 2. Figure 3 gives continuous measurements of anomalies and altimeter records for air traverses $A, B, C$, and D located on figures 1 and 2. The prominent anomaly is on traverse B. Ground anomalies were measured at 3-m (10-ft) intervals and are shown on figure 4 for traverse A82, figure 5 for traverse A83, figure 6 for traverse B83, and figure 7 for traverse C83. Ground traverse $\mathrm{H} 82$ is shown by Bath and Jahren (1984) on their figure 20. Ground anomalies measured close to magnetized rock have very irregular shapes, and a severe method of smoothing was used to convert them to a form resembling air anomalies. Each traverse was smoothed by continuation upward $122 \mathrm{~m}$ ( $400 \mathrm{ft}$ ) by the method of Henderson and Zietz (1949), and the resulting values were multiplied by a constant to restore the average value at ground level.

\section{MAGNETIC PROPERTIES}

The average total magnetization of a uniformaly magnetized rock mass, denoted as the vector $\vec{J}_{t}$ is defined as the vector sum of the induced magnetization, $\vec{j}_{i}$, and remanent magnetization, $\vec{J}_{r}$ :

$$
\vec{j}_{t}=\vec{j}_{i}+\vec{j}_{r}
$$

Air and ground magnetic surveys will commonly detect an ash or lava flow when its average total magnetization is equal to or greater than $0.05 \mathrm{~A} / \mathrm{m}$ (Bath, 1968). Therefore, units having intensities less than $0.05 \mathrm{~A} / \mathrm{m}$ are herein designated nonmagnetic; and those having greater intensities are herein arbitrarily designated as either weakly, moderately, or strongly magnetized as defined by the following limits:

\author{
nonmagnetic $\leq 0.05 \mathrm{~A} / \mathrm{m}$ \\ $0.05 \mathrm{~A} / \mathrm{m}<$ weakly magnetized $<0.50 \mathrm{~A} / \mathrm{m}$ \\ $0.50 \mathrm{~A} / \mathrm{m}<$ moderately magnetized $<1.50 \mathrm{~A} / \mathrm{m}$ \\ $1.50 \mathrm{~A} / \mathrm{m}<$ strongly magnetized
}




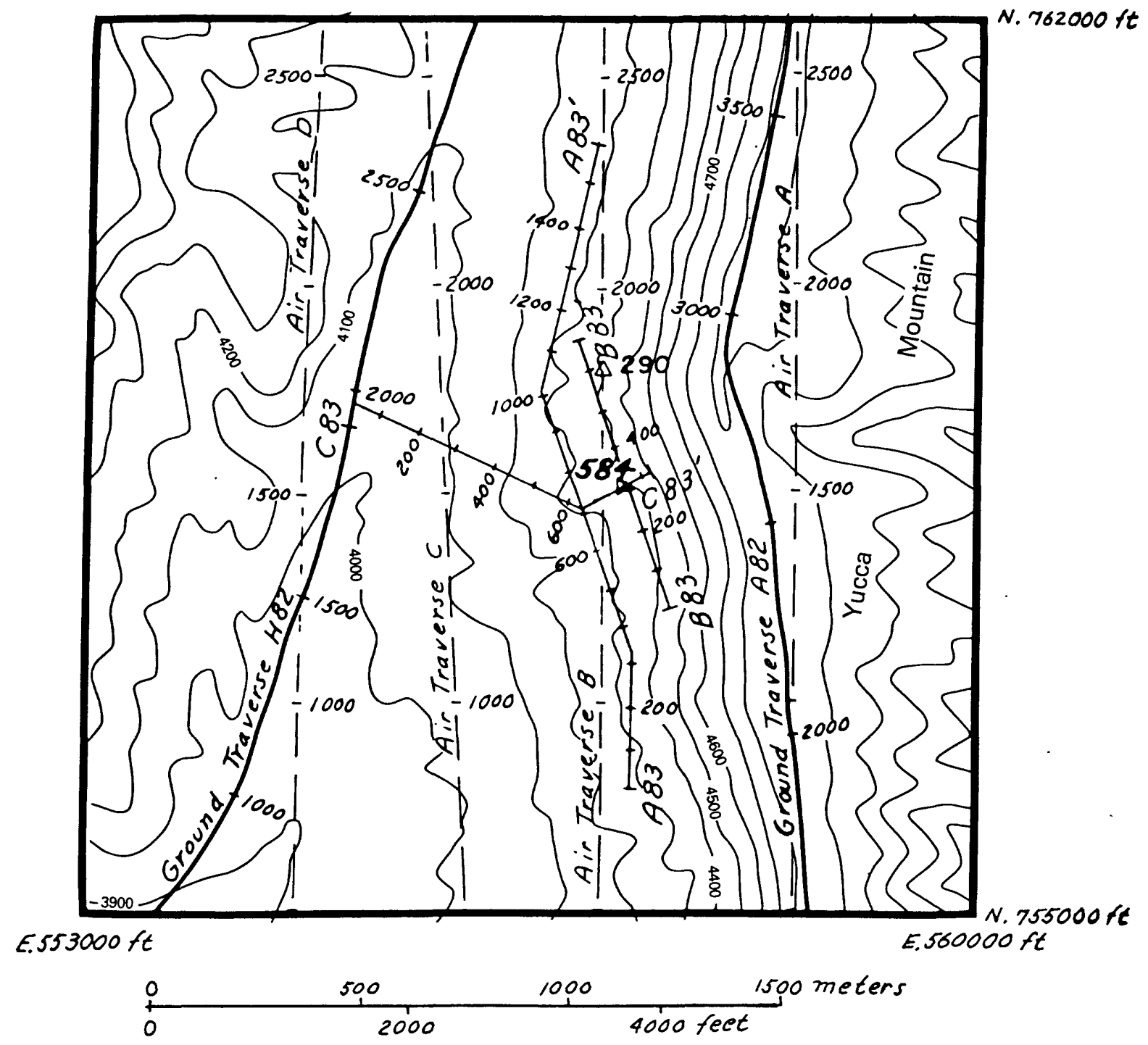

Figure 2.--Topographic map of area west of Yucca Mountain showing air traverses A, B, C, and D; and ground traverses A82, H82, $\mathrm{A} 83, \mathrm{~B} 83$, and $\mathrm{C} 83$. Traverse distances are in meters. Triangles give locations of anomaly maxima: $290 \mathrm{nT}$ on air traverse $\mathrm{B}$, and $584 \mathrm{nT}$ on ground traverse C83. Contour interval is 20 feet. 

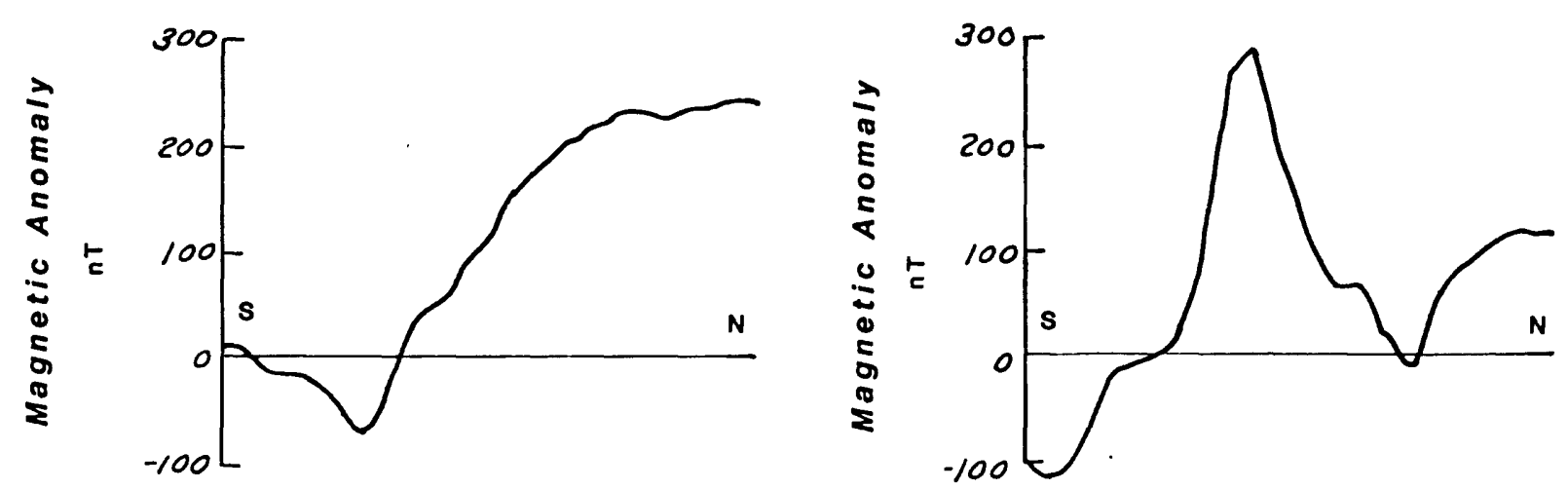

\section{Air A}

$\operatorname{Air} A^{\prime}$
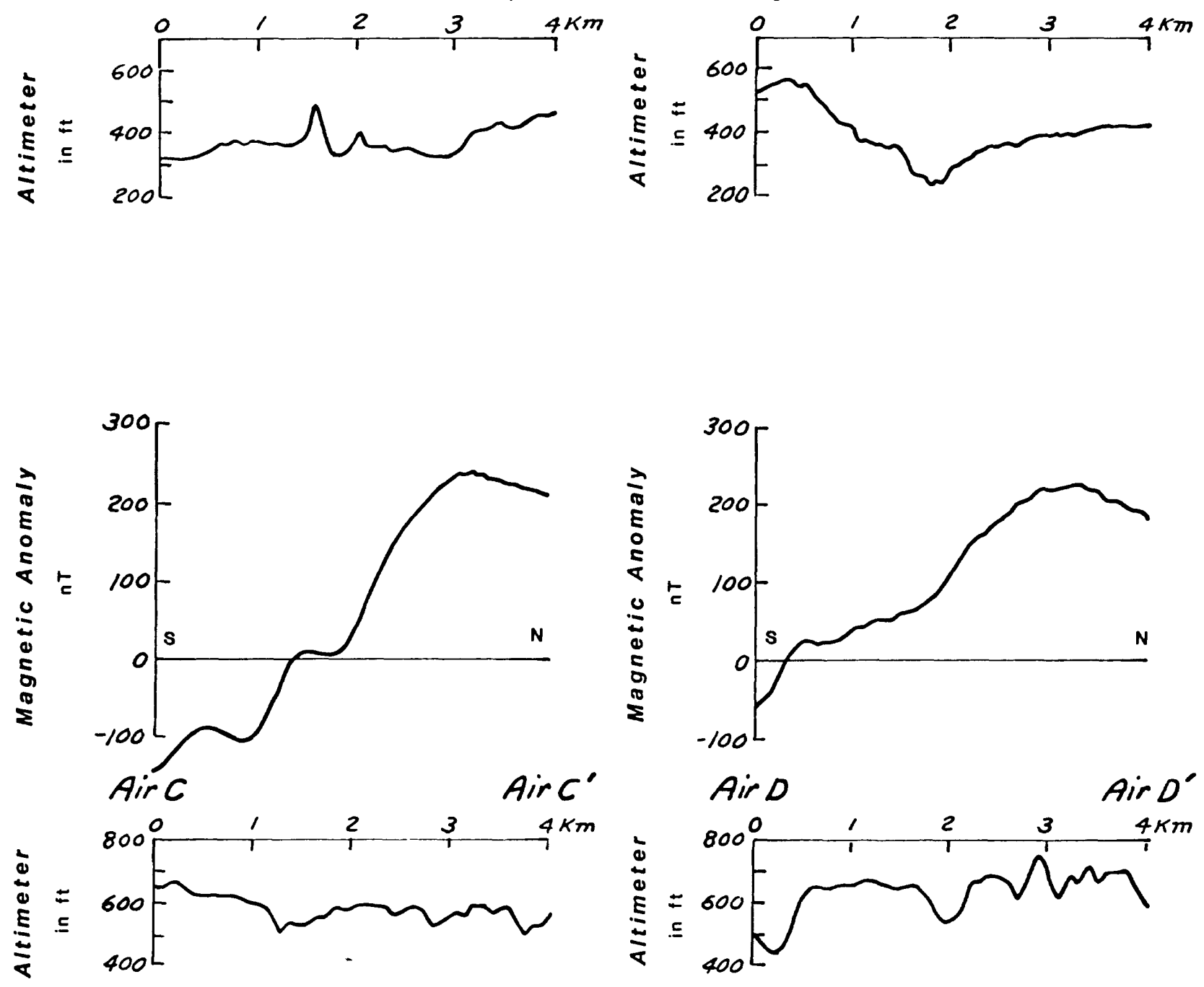

Figure 3.--Residual anomalies and altimeter records for air traverses A, B, C, and $\mathrm{D}$. The altimeter gives distance from airplane to ground surface in feet. 


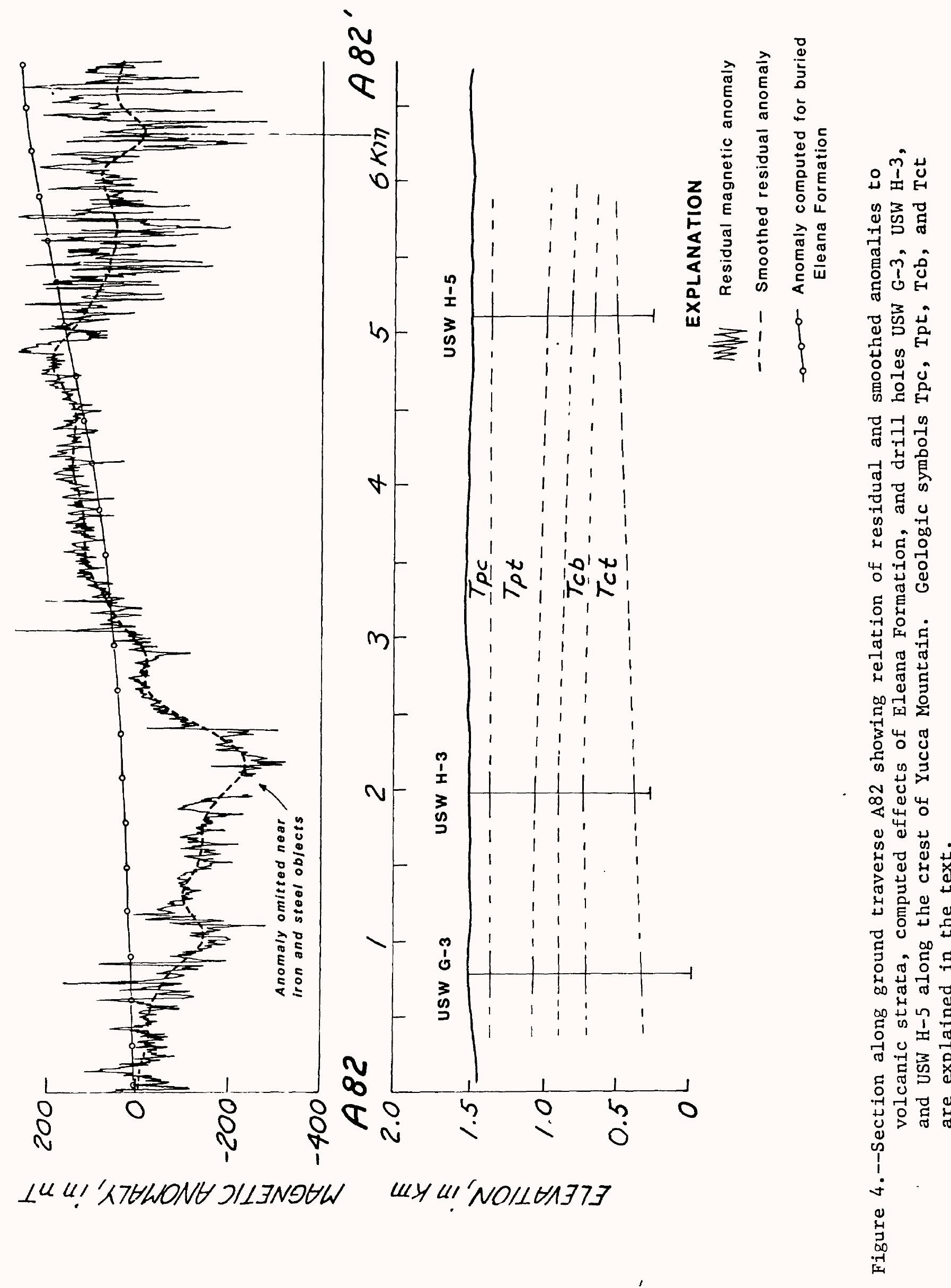



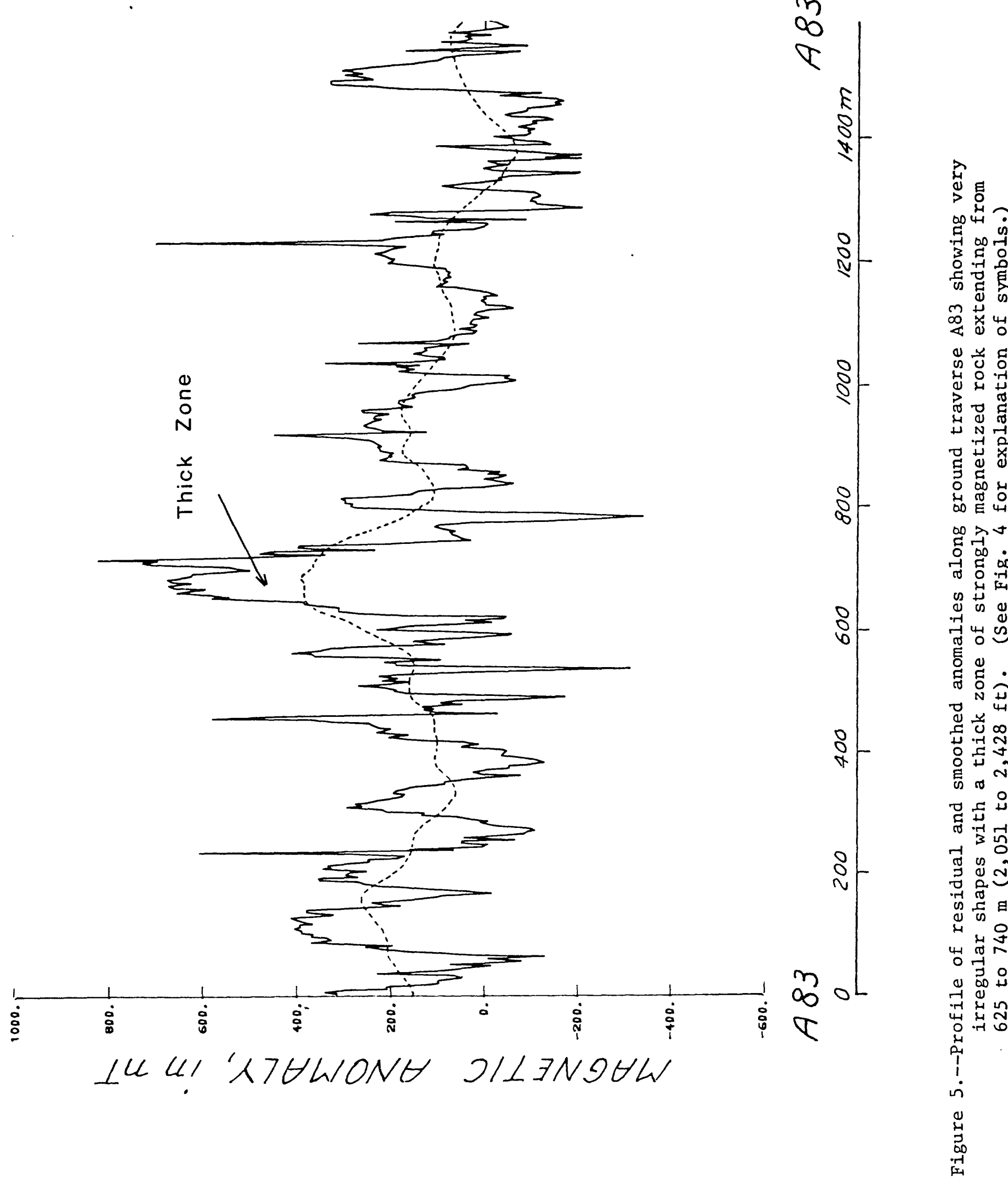


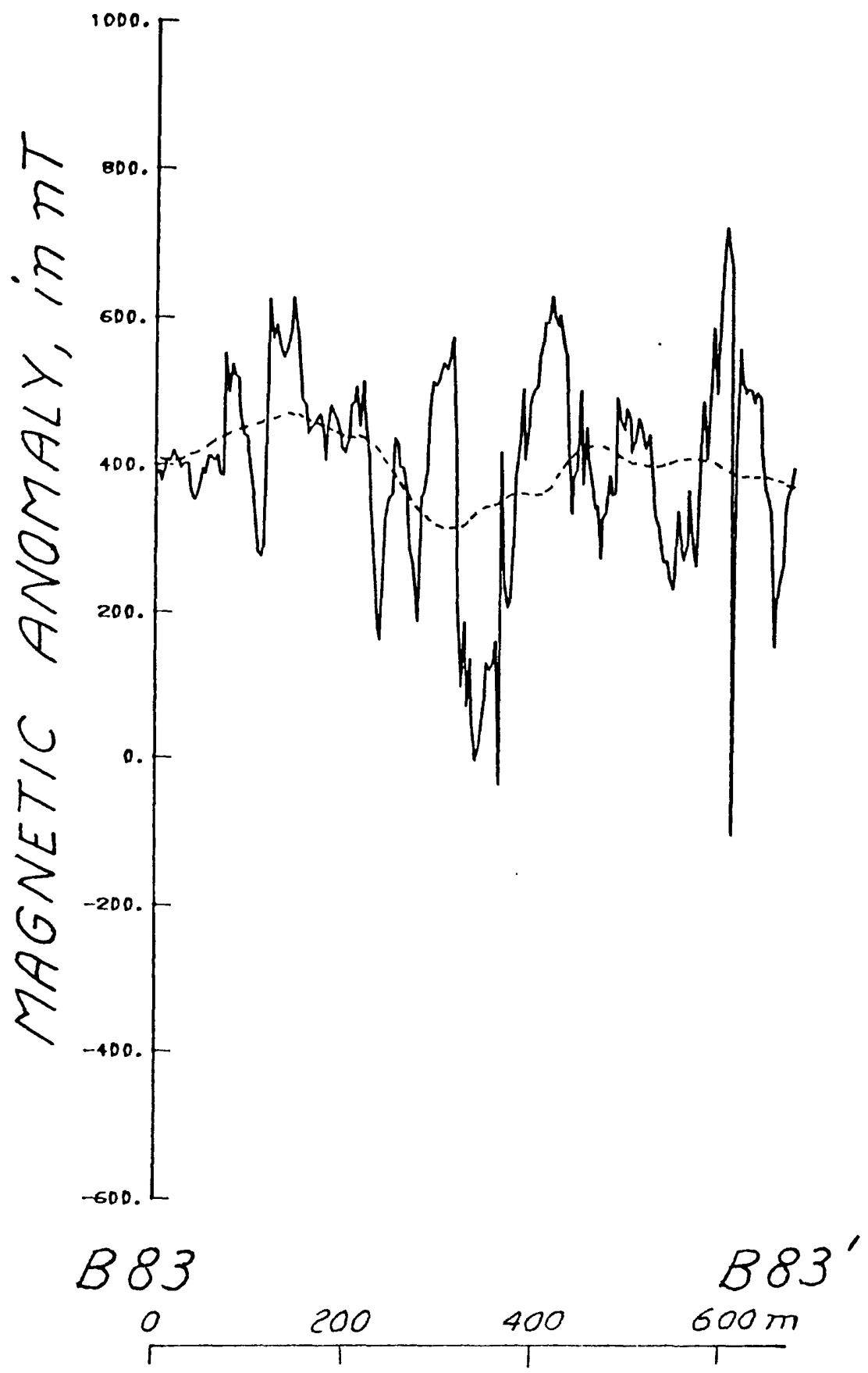

Figure 6.--Profile of residual and smoothed anomalies along ground traverse B83. (See fig. 4 for explanation of symbols.) 


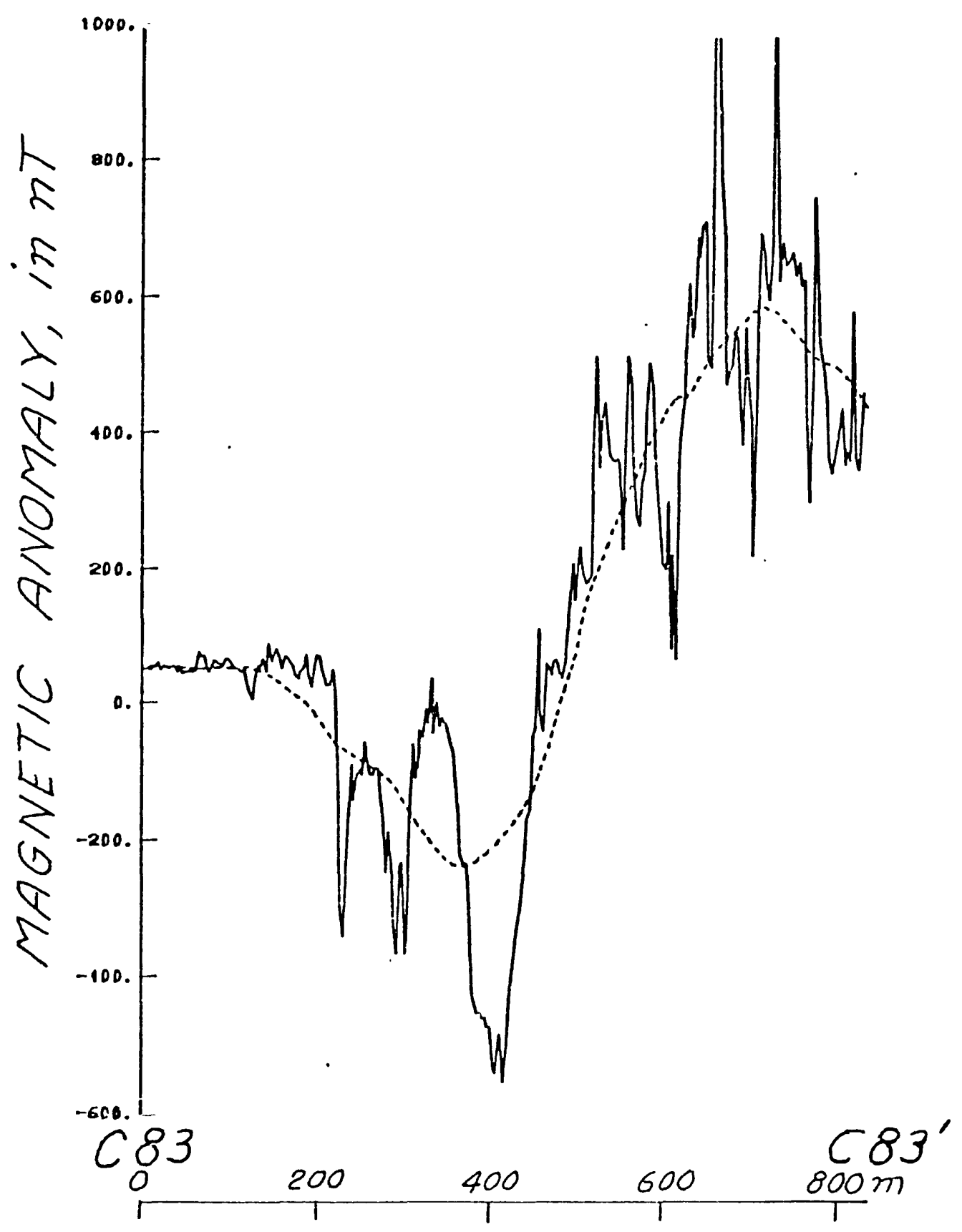

Figure 7.--Profile of residual and smoothed anomalies along ground traverse C83 showing a smoothed maximum of $584 \mathrm{nT}$ at $707 \mathrm{~m}(2,320 \mathrm{ft})$. (See fig. 4 for explanation of symbols.) 
Total magnetizations varying from nonmagnetic to strongly magnetic and of both normal and reversed polarities, were found in drill core samples from geologic exploration holes and surface samples in the Yucca Mountain area Rosenbaum and Snyder, 1985). Large changes in magnetic intensity occur both laterally and vertically within the volcanic ash-flow sheets. Average magnetizations were determined for units mapped by Lipman and McKay (1965) and Scott and Bonk (1984), and penetrated in drill holes USW G-1 (Spengler and others, 1981), USW G-2 (Maldonado and Koether, 1983), and USW G-3 and USW GU-3 (Scott and Castellanos, 1984). The magnetic intensity values suggest the following eight units as possible anomaly producers in the vicinity of major faults in the Yucca Mountain area:

Rainier Mesa Member of the Timber Mountain Tuff (Tmr) Tiva Canyon Member of the Paintbrush Tuff (Tpc)

Pah Canyon Member of the Paintbrush Tuff (Tpp)

Topopah Spring Member of the Paintbrush Tuff (Tpt)

Bullfrog Member of the Crater Flat Tuff (Tcb)

Tram Member of the Crater Flat Tuff (Tct)

Lava flow and flow breccia (Tfb)Lava and flow breccia (T11)

Considerations of thicknesses, and lateral extent of units has narrowed the eight to the Tiva Canyon, Topopah Spring, Bullfrog, and Tram Members. Their average magnetic properties and thicknesses are given in table 1. Modelling studies by Bath and Jahren (1984) showed a close resemblance between observed aeromagnetic anomalies in the Yucca Mountain area and theoretical anomalies computed for the faulted Topopah Spring Member. Their study designated the Topopah Spring Member as the most likely primary source of aeromagnetic anomalies.

\title{
Estimate of Magnetization
}

The method of estimating total magnetization by Smith (1961, equation 2.7) has been modified and applied to ground magnetic anomalies arising from near surface rocks in the NTS area by Bath and others (1983) and Bath and Jahren (1984). The estimates are based on the irregular and abrupt changes in anomaly amplitudes and shapes found in many ground traverses, and on the method of estimating depths to anomaly sources by Vacquier and others (1951). It is thus possible to use anomaly amplitudes to give minimum estimates of total magnetization within the following limits:

\author{
nonmagnetic $\leq 15 \mathrm{nT}$ \\ $15 \mathrm{nT}<$ weakly magnetized $<150 \mathrm{nT}$ \\ $150 \mathrm{nT}<$ moderately magnetized $<450 \mathrm{nT}$ \\ $450 \mathrm{nT}<$ strongly magnetized
}


Table 1.--Magnetic properties and thicknesses of four units that were penetrated in three holes drilled on Yucca Mountain. These are the most 1ikely sources of magnetic anomalies

\begin{tabular}{|c|c|c|c|c|c|}
\hline Unit & $\begin{array}{l}\text { Drill } \\
\text { hole }\end{array}$ & $\begin{array}{l}\text { Magnetic } \\
\text { polarity } \\
\end{array}$ & $\begin{array}{r}\mathrm{J}_{\mathrm{t}} \\
(\mathrm{A} / \mathrm{m}) \\
\end{array}$ & $\begin{array}{l}\text { Thickness } \\
\text { (m) }\end{array}$ & Comments \\
\hline $\mathrm{Tpc}$ & USW G-3 & Reversed & 0.9 & 103 & Entire unit \\
\hline $\begin{array}{l}\text { Tpt } \\
\text { Do. } \\
\text { Do. } \\
\text { Do. } \\
\text { Do. } \\
\text { Do. } \\
\text { Do. }\end{array}$ & $\begin{array}{l}\text { USW G-1 } \\
\text { do. } \\
\text { do. } \\
\text { USW G-2 } \\
\text { do. } \\
\text { do. } \\
\text { USW G-3 }\end{array}$ & $\begin{array}{c}\text { Normal } \\
\text { do. } \\
\text { do. } \\
\text { do. } \\
\text { do. } \\
\text { do. } \\
\text { do. }\end{array}$ & $\begin{array}{l}1.3 \\
0.7 \\
2.0 \\
1.4 \\
0.7 \\
1.7 \\
1.2 \\
1.3\end{array}$ & $\begin{array}{l}335 \\
169 \\
166 \\
285 \\
102 \\
183 \\
272 \\
297\end{array}$ & $\begin{array}{l}\text { Entire unit } \\
\text { upper part } \\
\text { lower part } \\
\text { Entire unit } \\
\text { upper part } \\
\text { lower part } \\
\text { Entire unit } \\
\text { Average for entire unit }\end{array}$ \\
\hline $\begin{array}{l}\text { Tcb } \\
\text { Do. } \\
\text { Do. }\end{array}$ & $\begin{array}{ll}\text { USW } & \text { G-1 } \\
\text { USW } & \text { G-2 } \\
\text { USW } & \text { G-3 }\end{array}$ & $\begin{array}{l}\text { Normal } \\
\text { do. } \\
\text { do. }\end{array}$ & $\begin{array}{l}1.0 \\
0.2 \\
3.0 \\
1.4\end{array}$ & $\begin{array}{l}130 \\
128 \\
182 \\
147\end{array}$ & $\begin{array}{l}\text { Entire unit } \\
\text { Entire unit (altered) } \\
\text { Entire unit } \\
\text { Average for entire unit }\end{array}$ \\
\hline $\begin{array}{l}\text { Tct } \\
\text { Do. } \\
\text { Do. } \\
\text { Do. } \\
\text { Do. }\end{array}$ & $\begin{array}{l}\text { USW G-1 } \\
\text { do. } \\
\text { do. } \\
\text { USW G-2 } \\
\text { USW G-3 }\end{array}$ & $\begin{array}{l}\text { Reversed } \\
\text { do. } \\
\text { do. } \\
\text { do. } \\
\text { do. }\end{array}$ & $\begin{array}{l}1.2 \\
2.0 \\
0.1 \\
0.2 \\
1.8 \\
1.1\end{array}$ & $\begin{array}{l}268 \\
142 \\
126 \\
128 \\
\frac{369}{255}\end{array}$ & $\begin{array}{l}\text { Entire unit } \\
\text { upper part } \\
\text { lower part (altered) } \\
\text { Entire unit (altered) } \\
\text { Entire unit } \\
\text { Average for entire unit }\end{array}$ \\
\hline
\end{tabular}


Estimates of magnetization based on ground anomalies range from weak to strong for near surface portions of rock units mapped along the crest and west of Yucca Mountain. Figure 2 shows the ground traverses, figure 8 shows the geologic units, and figures $4,5,6$, and 7 show the anomalies.

Like the laboratory measurements of magnetic properties, estimates from ground magnetic anomalies indicate changes in magnetic intensity within the welded tuffs. For example, a lateral change from weak to moderate magnetization is revealed for the Tiva Canyon Member by abrupt changes in the residual anomalies shown in traverse A82 ( $\mathrm{fig}$. 4) which extend for a total distance of $6,860 \mathrm{~m}(22,500 \mathrm{ft})$ along the crest of Yucca Mountain. Amplitudes average about $50 \mathrm{nT}$ for the first $4,900 \mathrm{~m}(16,075 \mathrm{ft})$ and about $200 \mathrm{nT}$ for the remaining $1,960 \mathrm{~m}(6,425 \mathrm{ft})$. This northward increase is in the upper part of the member. As shown on figure 4, the anomaly datum is $115 \mathrm{~m} \mathrm{(375} \mathrm{ft)} \mathrm{above}$ the base of the member in drill hole USW G-3 (Scott and Castellanos, 1984), and $150 \mathrm{~m}$ ( $490 \mathrm{ft}$ ) above the base of the member of drill hole USW H-5 (Bentley and others, 1983).

Most of the irregular anomalies on traverses A83 (fig. 5) and B83 (fig. 6) and on the eastern part of traverse C83 ( $f i g \cdot 7$ ), are above exposures of the Topopah Spring Member and indicate moderate magnetizations. A few isolated anomalies have amplitudes greater than $450 \mathrm{nT}$ and indicate strongly magnetized rock. A prominent example is the thick zone that extends from 625 $\mathrm{m}(2,050 \mathrm{ft})$ to $740 \mathrm{~m}(2,428 \mathrm{ft}$ ) on traverse A83 (fig. 5). Estimates based on anomaly shapes (Vacquier and others, 1951) mark out a mass of strongly magnetized rock about $115 \mathrm{~m}$ (378 ft) wide with its top about $30 \mathrm{~m}$ (100 ft) below the surface.

\section{ANOMALY INTERPRETATIONS}

Aeromagnetic surveys in the Nevada Test Site region were flown close enough to the surface to detect anomalies produced by major faults (Bath, 1976, Bath and others, 1983; Bath and Jahren, 1984). While the terrain clearances shown on figure 3 average about $122 \mathrm{~m}$ (400 ft) for traverses $A-A^{\prime}$ and $B-B^{\prime}$ and about $183 \mathrm{~m}(600 \mathrm{ft})$ for traverses $C-C^{\prime}$ and $D^{\prime} D^{\prime}$, there are some notable deviations. One obvious example is the interval decrease on traverse $B-B^{\prime}$ beneath the prominent aeromagnetic anomaly. Barometric altimeter readings indicate the elevation of the aircraft was about constant, and therefore, the decrease in terrain clearance reflects changes in topographic relief beneath the flight path. There is a small westward bend in the northward trend of Yucca Mountain, and figure 2 shows that the flight path crosses this feature.

A qualitative interpretation suggests the decrease in interval from airplane to surface is the source of the $290 \mathrm{nT}$-air anomaly. A positive anomaly would be expected in measurements closer to the surface of a normally magnetized ash flow; and there are approximate correlations of positions of anomaly maximum (fig. 1), westward bend of Yucca Mountain (fig. 2), and minimum interval (fig. 3). However, a depth estimate from anomaly $B-B^{\prime}$ of figure 3 places the source too deep to be explained by effects of terrain clearance alone. Some other source, or sources, must be present and have a contributing effect that distorts the shape of the anomaly that gives the misleading depth estimate. Quantitative interpretations were therefore undertaken to investigate other possible sources. The ground traverses proved 


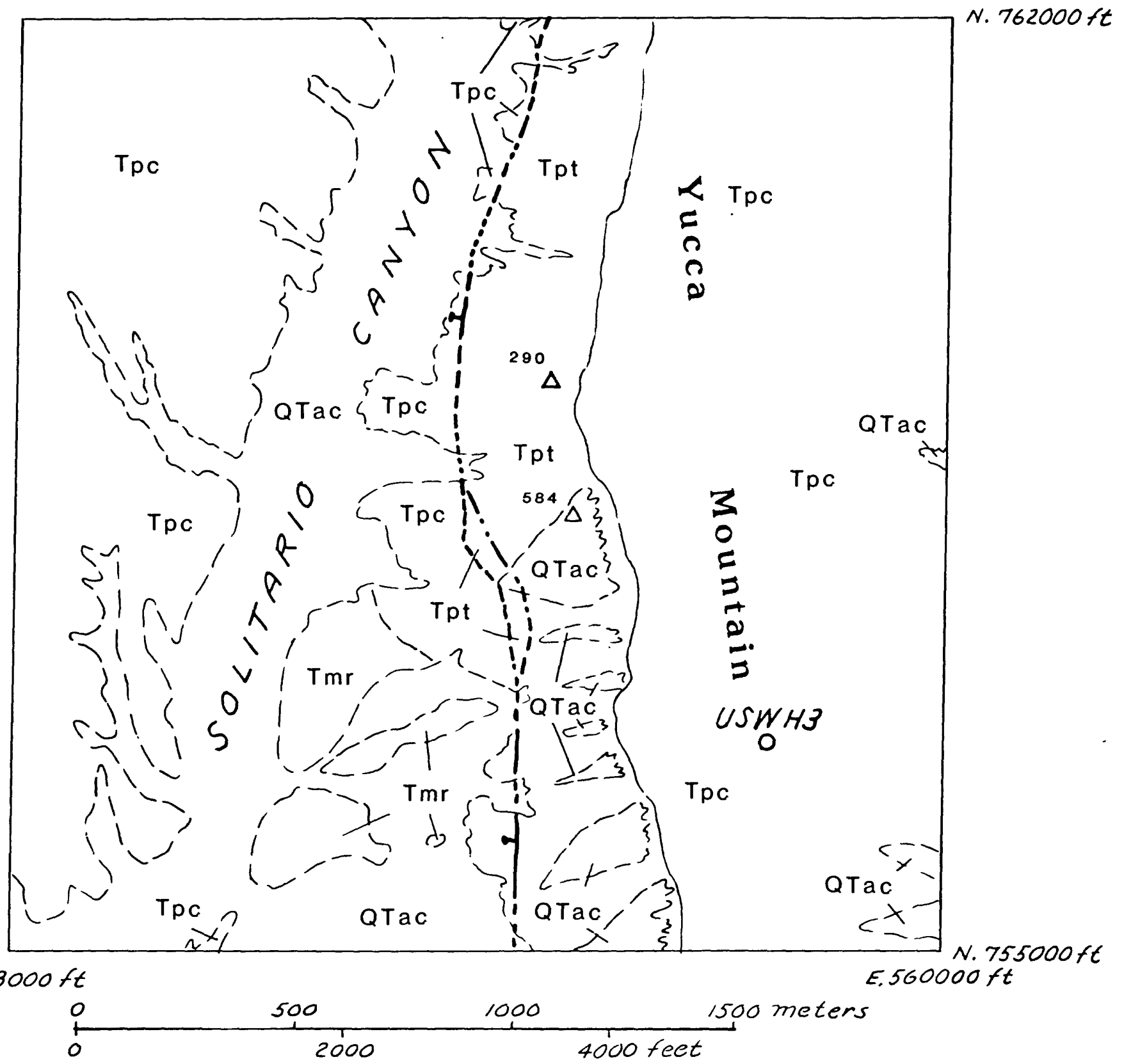

Figure 8.--Geologic map of western part of Yucca Mountain showing exposures of volcanic units (symbols are explained in text) and alluvium and colluvium (QTac); and the mapped trace of the Solitario Canyon fault that trends northward across the central part of the map. Also shown are locations of 290-nT air maximum and 584-nT ground maximum. Geology is from Scott and Bonk (1984). 
to be an important part of the studies. They showed the effects of other possible sources, and not the effect of a decrease in interval between airplane and ground surface.

\section{Aeromagnetic Anomalies}

The pair of parallel aeromagnetic anomalies that trend north-south along the west side of Yucca Mountain (Bath and Jahren, 1984, figs. 12, 15, and 17) are explained as the edge effects of volcanic tuff displayed by the Solitario Canyon fault. The anomalies are negative over the low-standing side and positive over the high-standing side of the fault. The prominent anomaly on traverse $B-B^{\prime}$ of figure 3 is on the high-standing side, but its maximum of 290 $\mathrm{nT}$ is $135 \mathrm{nT}$ greater than maximum on a east-west flight line that intersects $B-B^{\prime}$ to the south. Positive anomalies also are found on lines flown northsouth near traverse $B-B^{\prime}$ The broad positive anomalies on traverses $A-A^{\prime}, C-$ $C^{\prime}$, and $D_{-} D^{\prime}$ (fig. 3) were interpreted by Bath and Jahren as arising from a strongly magnetized source, possibly altered Eleana Formation like that at Calico Hills (Baldwin and Jahren, 1982), at a depth of about 2,250 m (7,400 $\mathrm{ft}$ ) underlying the volcanic rocks penetrated in drill holes at Yucca Mountain.

As shown on figure 9, the $290 \mathrm{nT}$ anomaly can be explained by three sources: a dipole or a finite prism (Source $A$ ) that represents an increase in magnetization, and an infinite vertical prism (Source B) that represents a small intrusive. This assumes no anomaly arising from the effect of terrain clearance. Table 2 gives the total magnetization of the sources, and table 3 gives the amplitudes of the computed anomalies.

The increase in magnetization indicated by the magnetic dipole and Source $A$ is $625 \mathrm{~m}(2,050 \mathrm{ft})$ below the air datum, or at a depth of $549 \mathrm{~m}(1,800$ $\mathrm{ft})$. This places the source below the Topopah Spring Member of the Paintbrush Tuff and within the Bullfrog Member of the Crater Flat Tuff. The computed direction of magnetization in table 2 is about midway between normal and reverse, and suggests a body having a reversed thermoremanant magnetization with a substantial normal component of isothermal remanant magnetization. This is a significant deviation from the known normal polarity of the Bullfrog Member and from the intensity of $32.86 \mathrm{~A} / \mathrm{m}$, which is too large for the member. The reversed polarity would be more reasonable for a basaltic dike, and even the high intensity of $8.32 \mathrm{~A} / \mathrm{m}$ is a possibility.

The models offer an opportunity to investigate effects of positioning the airplane closer to the ground surface. As shown in table 3, reducing the elevation by $61 \mathrm{~m}(200 \mathrm{ft})$ increases the amplitude by only about $70 \mathrm{nT}$, or about half of the $135 \mathrm{nT}$ difference between maximum of $290 \mathrm{nT}$ on north-south traverse $B-B^{\prime}$ of figure 1 and the maximum of $155 \mathrm{nT}$ on the nearby east-west traverse (fig. 12 of Bath and Jahren, 1984). This indicates the sources are too deep for this change in elevation to explain the prominent aeromagnetic anomaly.

\section{Ground Magnetic Anomalies}

Another source for the prominent air anomaly is suggested by the positive values of smoothed ground anomalies that increase abruptly eastward with increasing distance from the Solitario Canyon fault. Figures 2 and 8 show the relationships between positions of traverses and faults, and also show that the small westward bend in the northward trend of Yucca Mountain is accompanied by a similar bend in the Solitario Canyon fault. The positive 

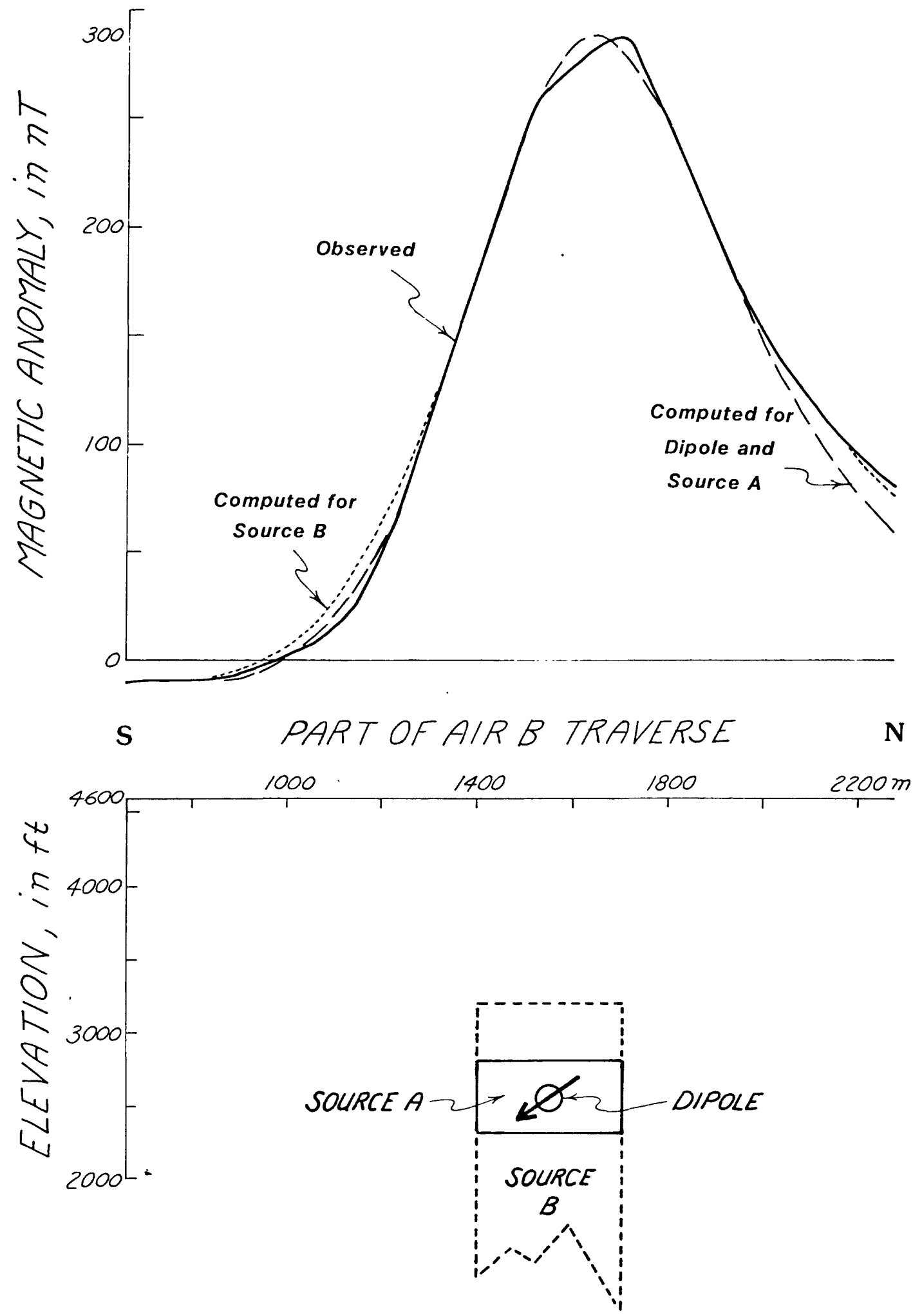

Figure 9.--Section along part of air traverse $B^{-} B^{\prime}$ showing close comparisons between the observed anomaly and anomalies computed for a dipole, source A, and source B. Source A represents an increase in magnetization within a vertical prism with length $=$ width $=$ $305 \mathrm{~m}(1,000 \mathrm{ft})$ and thickness $=152 \mathrm{~m}(500 \mathrm{ft})$. Source B represents a small intrusive with length $=$ width $=305 \mathrm{~m}(1,000$ $f t)$ and thickness = infinity. 
Table 2.--Total magnetizations for models of figure 9

\begin{tabular}{cccc} 
Model & $\begin{array}{c}\text { Inteysity } \\
(\mathrm{A}) \mathrm{m})\end{array}$ & $\begin{array}{c}\text { Azimuth } \\
\text { (degrees) }\end{array}$ & $\begin{array}{c}\text { Inclination }^{2} \\
(\text { degrees }\end{array}$ \\
\hline Dipole & & 16 & 145 \\
A & 14,500 & 16 & 145 \\
B & 32.86 & 16 & 145
\end{tabular}

1 Measured clockwise from north.

2 Measured down from a northward horizontal axis.

3 Small cube with volume $=2.83 \times 10^{4} \mathrm{~m}^{3}$.

Table 3.--Aeromagnetic anomalies computed for models of figure 9

AMPLITUDE OF RESIDUAL AEROMAGNETIC ANOMALY

Mode 1

\begin{tabular}{|c|c|c|c|c|c|c|}
\hline 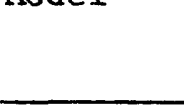 & $\begin{array}{l}\text { Depth } \\
\text { (m) }\end{array}$ & $\begin{array}{l}\text { to top } \\
\text { (ft) }\end{array}$ & $\begin{array}{l}\text { Maximum } \\
\text { (nT) }\end{array}$ & $\begin{array}{l}\text { Minimum } \\
\text { (nT) }\end{array}$ & $\begin{array}{l}\text { Total } \\
\text { (nT) }\end{array}$ & $\begin{array}{l}\text { in total } \\
\text { (nT) }\end{array}$ \\
\hline Dipole & 625 & $2,050^{1}$ & 261 & -36 & $297^{1}$ & 71 \\
\hline Dipole & 686 & $2,250^{1}$ & 199 & -27 & 226 & \\
\hline Source A & 549 & 1,800 & 259 & -38 & $297^{2}$ & 69 \\
\hline Source A & 610 & 2,000 & 199 & -29 & 228 & \\
\hline Source B & 427 & 1,400 & 279 & -18 & $297^{2}$ & 66 \\
\hline Source B & 488 & 1,600 & 219 & -12 & 321 & \\
\hline
\end{tabular}

Difference

1 Depth is to center of dipole.

2 The anomaly shown in figure 9. 
values average about $150 \mathrm{nT}$ along traverse A83-A83' which is about paralle1 to and $100 \mathrm{~m}$ ( $300 \mathrm{ft}$ ) east of the fault. The average values increase to about $350 \mathrm{nT}$ on traverse B83-B83' which is $120 \mathrm{~m}$ (400 ft) east of traverse A83-A83' and nearer the position of the air maximum. A similar increase is expected in the air anomalies. Air traverse $B-B^{\prime}$ was flown along a straight line and its distance from the fault increases in the area of the air maximum.

The ground data measured beneath air traverse $B-B^{\prime}$ supports an interpretation of change in terrain clearance, but not an interpretation of an increase in magnetization at a depth of $549 \mathrm{~m}(1,800 \mathrm{ft})$ or a basaltic dike at depth of $427 \mathrm{~m}(1,400 \mathrm{ft})$. The smoothed anomalies of traverse A83-A83' do not show a prominent anomaly having the amplitude to explain the air anomaly or the long wavelength to explain sources at depth. Almost all the unsmoothed anomalies have the short wavelengths that are produced by changes in rock magnetization in narrow zones near the surface. The thick zone of stronglymagnetized rock ( $\mathrm{fig} .5$ ) is about $300 \mathrm{~m}$ (1,000 ft) south of the aeromagnetic maximum, and it is described in the section "Estimate of Magnetization". Traverse C83-C83' was measured in an east-west direction to delineate effects of the thick zone and the Solitario Canyon fault.

The smoothed anomaly of traverse C83-C83' was then analyzed to investigate the source of the thick zone and its effects at the elevations of the aeromagnetic anomalies. There is reliable information for the geology and magnetic properties of the flows displaced by the fault, and a threedimensional forward program was used to model the high- and low-standing components of the fault and two possible sources for the thick zone.

As shown on figure 10, the anomaly over the fault has a total amplitude of $822 \mathrm{nT}$ and can be modeled satisfactorily by the combined effects of faulted components of the Topopah Spring and Tiva Canyon Members, and the effects of either an increase in magnetization within the Topopah Spring Member (Source C) or a strongly magnetized intrusive body (Source D). Tuff magnetizations, estimated from anomaly amplitudes, are moderate near the fault and less than those from the drill-core samples of table 1, probably due to weathering; and the magnetizations of Sources C and D are strong. Aeromagnetic anomalies were computed from the models and compared with positive amplitudes measured $61 \mathrm{~m}$ $(200 \mathrm{ft})$ and $122 \mathrm{~m}$ ( $400 \mathrm{ft}$ ) above the surface. Table 4 gives the magnetization directions and intensities for the models, and table 5 gives the amplitudes of computed anomalies.

The wide zone is interpreted as either a very large increase of magnetization within the Topopah Spring Member or a small intrusive body. The magnetization increase is designated more likely because abrupt changes are common within tuffs of the site area. Changes in drill-core samples are reported by Rosenbaum (1985), and other zones of strong magnetization were estimated from the anomaly amplitudes along ground traverse A83 of figure 5. Geological evidence in the area of the anomaly also argues against the possibility of a near surface intrusive. No change in appearance of surface rocks or effects of heating was noted. However, basalt float has been found at a lower elevation and about $1 / 2 \mathrm{mi}$ south of the anomaly (R. B. Scott, USGS, oral commun., 1984). 
As shown on figure 10 and in table 5, the wide zone as Source $C$ will produce a significant anomaly of $86 \mathrm{nT}$ at $122 \mathrm{~m}$ ( $400 \mathrm{ft}$ ) above the surface. This is the difference between the maximum effects of the fault, $186 \mathrm{nT}$; and the maximum effects of the fault plus Source $C, 272 \mathrm{nT}$. A decrease in $61 \mathrm{~m}$ $(200 \mathrm{ft}$ ) in flight elevation (table 5) increases computed maxima by $54 \mathrm{nT}$ for the fault, $89 \mathrm{nT}$ for Source $C$, and $101 \mathrm{nT}$ for Source D. 

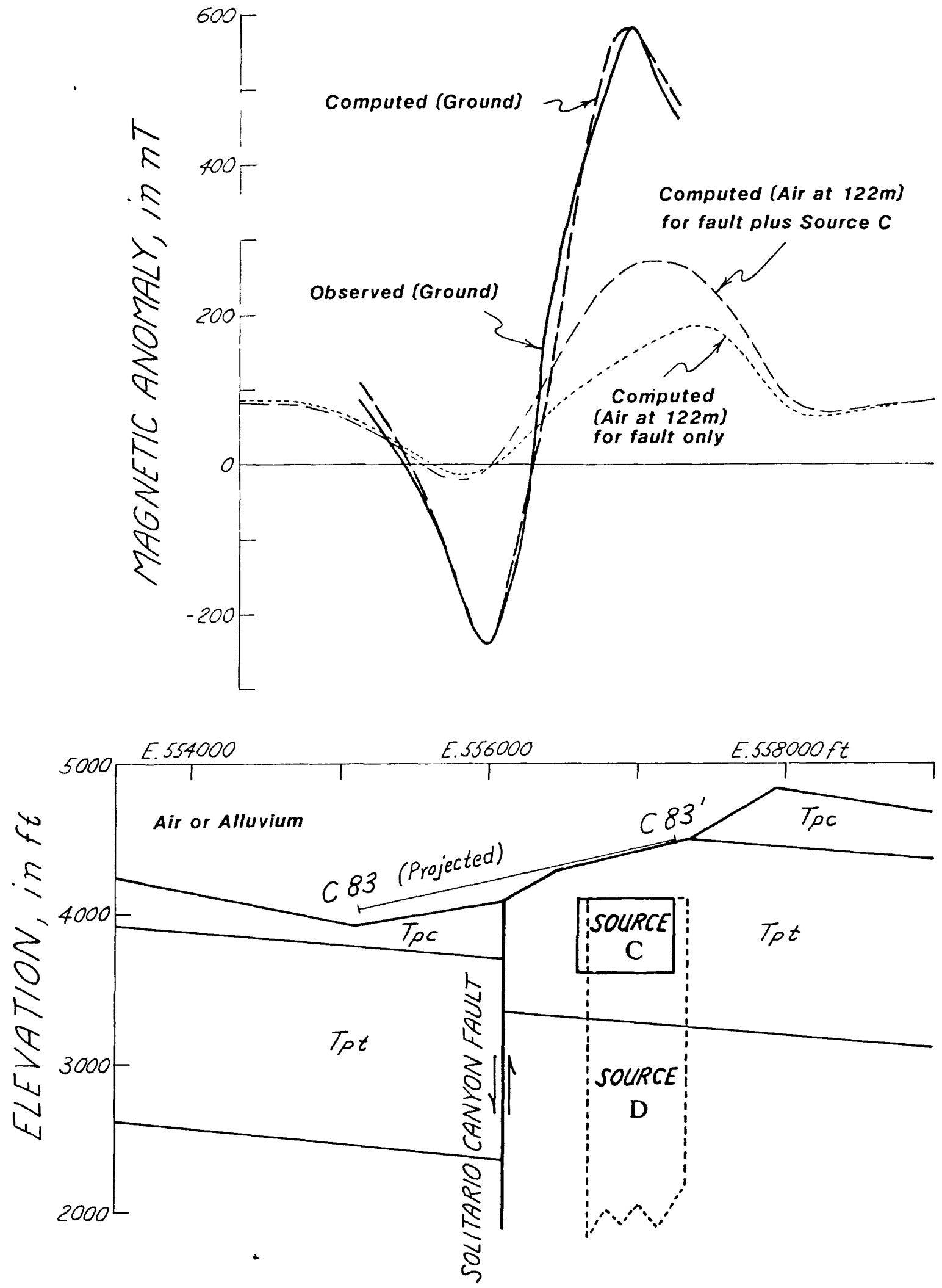

Figure 10.--Section across the Solitario Canyon fault on ground traverse C83C83' (projected) showing close comparisons between the observed anomaly and summations of anomalies computed for horizontal prisms that represent the Tiva Canyon Member (Tpc) and the Topopab Spring Member (Tpt); and for vertical prisms that represent an increase in magnetization (Source $C$ ) or magma pipe (Source D). The horizontal prisms extend along the fault strike for a distance of $3,048 \mathrm{~m}(10,000 \mathrm{ft})$. Source $C$ has a width $=198 \mathrm{~m}(650 \mathrm{ft})$ along the traverse and its north-south length $=$ depth extent $=152 \mathrm{~m}(500 \mathrm{ft})$. Source $\mathrm{D}$ has the same length and width as Source $C$, but its depth extent is infinite. 
Table 4.--Total magnetizations of component parts of models of figure 10

\begin{tabular}{lccc} 
Component & $\begin{array}{c}\text { Intensity } \\
(\mathrm{A} / \mathrm{m})\end{array}$ & $\begin{array}{c}\text { Azimuth }^{1} \\
\text { (degrees) }\end{array}$ & $\begin{array}{c}\text { Inclination } \\
\text { (degrees) }^{2}\end{array}$ \\
\hline Tiva Canyon tuff & 0.75 & 167 & -38 \\
Topopah Spring tuff & 0.75 & 326 & 62 \\
Source C & 3.73 & 326 & 62 \\
Source D & 3.26 & 0 & 62.5 \\
\hline
\end{tabular}

1 Measured clockwise from north.

2 Measured down from a northward horizontal axis.

Table 5.--Ground magnetic and aeromagnetic anomalies computed for models of figure 10

AMPLITUDE OF RESIDUAL MAGNETIC ANOMALY

\begin{tabular}{|c|c|c|c|c|c|}
\hline Component & Type & $\begin{array}{l}\text { Maximum } \\
(\mathrm{nT})\end{array}$ & $\begin{array}{l}\text { Difference } \\
\text { in maximum } \\
(\mathrm{nT})\end{array}$ & $\begin{array}{l}\text { Minimum } \\
(\mathrm{nT})\end{array}$ & $\begin{array}{l}\text { Tota1 } \\
(\mathrm{nT})\end{array}$ \\
\hline $\begin{array}{l}\text { Faulted components plus } \\
\text { either source } C \text { or } D\end{array}$ & Ground & 584 & & -238 & $822^{1}$ \\
\hline Faulted components only & Air ${ }^{2}$ & 240 & 54 & -66 & $306^{3}$ \\
\hline $\begin{array}{l}\text { Faulted components only } \\
\text { Faulted components plus } \\
\text { source } C\end{array}$ & $\begin{array}{l}\text { Ai } r^{4} \\
\text { Ai } r^{2}\end{array}$ & $\begin{array}{l}186 \\
361\end{array}$ & & $\begin{array}{l}-11 \\
-84\end{array}$ & $\begin{array}{l}197 \\
445\end{array}$ \\
\hline & & & 89 & & \\
\hline $\begin{array}{l}\text { Faulted components plus } \\
\text { source } C\end{array}$ & $\operatorname{Air} r^{4}$ & 272 & & -20 & $292^{5}$ \\
\hline $\begin{array}{l}\text { Faulted components plus } \\
\text { source } D\end{array}$ & $A i r^{2}$ & 413 & & -41 & 454 \\
\hline $\begin{array}{l}\text { Faulted components plus } \\
\text { source D }\end{array}$ & $\mathrm{Air}^{4}$ & 312 & 101 & 13 & 299 \\
\hline
\end{tabular}

1 The ground anomaly shown on figure 10 .

$261 \mathrm{~m}(200 \mathrm{ft})$ above ground traverse.

3 The air anomaly shown for fault only on figure 10 .

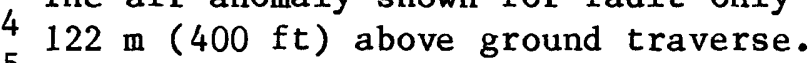

5 The air anomaly shown on figure 10 . 


\section{DISCUSSION}

The several single sources investigated did not give a satisfactory explanation of the prominent air anomaly. We believe the anomaly was produced by a combination of sources that include the magnetic effects of (1) reducing the interval from air datum to ground surface, (2) an increase of magnetization within the Topopah Spring Member of the Paintbrush Tuff, and (3) an increase in distance between the air datum and the Solitario Canyon fault. These interpretations do not require a significant change in the present understanding of the geology and magnetic properties of rocks within the area of the potential waste repository site. The presence of a small intrusive body would introduce a new concept, but the data now available do not favor this interpretation. 


\section{REFERENCES CITED}

Baldwin, M. J., and Jahren, C. E., 1982, Magnetic proporties of drill core and surface samples from the Calico Hills area, Nye County, Nevada: U.S. Geological Survey Open-File Report 82-536, 27 p.

Barraclough, R. R., and Fabiano, E. B., 1978, Grid values and charts for the International Geomagnetic Reference Field 1975: U.S. Geological Survey Report PB-276 630, 139 p.: available only from U.S. Department of Commerce, National Technical Information Service, Springfield, VA, 22161.

Bath, G. D., 1968, Aeromagnetic anomalies related to remanent magnetization in volcanic rock, Nevada Test Site, Nevada, in Nevada Test Site: Geological Society of America Memoir 110, p. 135-146.

Bath, G. D., 1976, Interpretation of magnetic surveys in intermontane valleys at Nevada and southern New Mexico: U.S. Geological Survey Open-File Report 76-440, $36 \mathrm{p}$.

Bath, G. D., Jahren, C. E., Rosenbaum, J. G., and Baldwin, M. J., 1983, Magnetic investigations, in Geoloic and geophysical investigations of Climax stock intrusive, Nevada: U.S. Geological Survey Open-File Report 83-377, p. 40-77.

Bath, G. D., and Jahren, C. E., 1984, Interpretations of magnetic anomalies at a potential repository site located in the Yucca Mountain area, Nevada Test Site: U.S. Geological Survey Open-File Report 84-120, 53 p.

Bentley, C. B., Robison, J. H., and Spengler, R. W., 1983, Geohydrologic data for test well USW H-5, Yucca Mountain area, Nye County, Nevada: U.S. Geological Survey Open-File Report 83-853, 34 p.

Henderson, R. G., and Zietz, Isidore, 1949, The upward continuation of anomalies in total magnetic intensity fields: Geophysics, v. 14, no. 4, p. 517-535.

Lipman, P. W., and McKay, E. J., 1965, Geologic map of the Topopah Spring SW quadrangle, Nye County, Nevada: U.S. Geological Survey Geologic Quadrangle Map GQ-439, scale 1:24,000.

Maldonado, Florian, and Koether, S. L., 1983, Stratigraphy, structure, and some petrographic features of Tertiary volcanic rocks at the USW G-2 drill hole, Yucca Mountain, Nye County, Nevada: U.S. Geological Survey Open-File Report 83-732, 83 p.

Rosenbaum, J. G., and Snyder, D. B., 1985, Preliminary interpretation of paleomagnetic and magnetic property data from drill holes USW G-1, G-2, GU-3, and VH-1 and surface localities in the vicinity of Yucca Mountain, Nye County, Nevada: U.S. Geological Survey Open-File Report 85-49, 73 p.

Scott, R. B., and Bonk, Jerry, 1984, Preliminary geologic map of Yucca Mountain, Nye County, Nevada with geologic sections: U.S. Geological Survey Open-File Report 84-494, scale 1:12,000. 
Scott, R. B., and Castellanos, Mayra, 1984, Stratigraphic and structural relations of volcanic rocks in drill holes USW GU-3 and USW G-3 Yucca Mountain, Nye County, Nevada: U.S. Geological Survey Open-File Report $84-491,121 \mathrm{p}$.

Smith, R. A., 1961, Some theorems concerning local magnetic anomalies: Geophysical Prospecting, v. 9, p. 399-410.

Spengler, R. W., Byers, F. M., Jr., and Warner, J. B., 1981, Stratigraphy and structure of volcanic rocks in drill hole USW-G1, Yucca Mountain, Nye County, Nevada: U.S. Geological Survey Open-File Report 81-1349, 50 p.

Vacquier, Victor, Steenland, N. C., Henderson, R. G., and Zietz, Isidore, 1951, Interpretation of aeromagnetic maps: Geological Society of America Memoir 47, $151 \mathrm{p}$. 